\title{
IMMUNIZATION STATUS OF RESIDENTS IN PEDIATRICS AT THE FEDERAL UNIVERSITY OF SÃO PAULO, BRAZIL
}

Mariana Bernardi Viviani SILVEIRA, Deborah Ascar PEREZ, Alessandra YAMAGUTI, Eduardo Zegna SARAIVA, Maria Gabriela BORGES \& Maria Isabel de MORAES-PINTO

\begin{abstract}
SUMMARY
Vaccination of health care workers is an efficient way to reduce the risk of occupational infection and to prevent nosocomial transmission to vulnerable patients. Despite this, achieving high immunization rates among those professionals is a challenge. We assessed the immunization status of Residents in Pediatrics at the Federal University of São Paulo from June to December 2008. Their immunization records were checked and evaluated according to the Brazilian Immunization Schedule for health care workers. Considering all required vaccines, only $3.1 \%$ of the 64 Residents were up-to-date with their immunizations. Influenza was the vaccine with the lowest uptake (3.1\%) and measles and rubella were diseases with the highest evidence of immunity (62.5\% each). Only $37.5 \%$ of Residents had received three hepatitis B vaccine doses with a subsequent serology confirming seroconversion. Moreover, the vast majority of Residents in Pediatrics who were not up-to-date were unaware of the fact. Both medical schools and Pediatric Residence programs should not only offer information but also check vaccination records in an effort to keep their healthcare workers' vaccinations up-to-date.
\end{abstract}

KEYWORDS: Health care workers; Immunization; Pediatrics.

\section{INTRODUCTION}

Health care workers (HCW) are under an increased risk of exposure to infectious diseases and of transmitting infection to vulnerable patients $^{11,19}$.

The Brazilian Ministry of Health proposes a special immunization schedule for this group, which includes vaccination against influenza, hepatitis B and varicella. These are in addition to the recommended immunization for all adults - tetanus, diphtheria, measles, mumps and rubella - and all are provided free of charge ${ }^{3}$.

Appropriate immunization of $\mathrm{HCW}$, in addition to decreasing the overall rate of disease among vaccinees, reduces the number of secondary cases, time associated to exposure management, and more importantly, provides protection to patients ${ }^{16,19}$.

This study aimed to assess the immunization status of Residents in Pediatrics at the Federal University of São Paulo, in São Paulo, Brazil.

\section{METHODS}

In Brazil, the Residence program consists of a specialization through a supervised internship after graduation in Medicine. Residence in
Pediatrics lasts at least two years. Data were collected at the São Paulo Hospital, a 752-bed, tertiary general hospital linked to the Federal University of São Paulo, in São Paulo, Brazil.

From June to December 2008, all the Residents in Pediatrics answered a questionnaire about their medical and vaccination history. Their immunization records were checked and vaccines previously administered were noted.

Individuals were evaluated according to the Brazilian Immunization Schedule for healthcare workers and were considered up-to-date if they had had: three tetanus/diphtheria (Td) vaccine doses, with the last dose/ booster within the last 10 years, one measles, mumps and rubella vaccine (MMR) dose or properly confirmed history of the diseases (laboratory evaluation for rubella and medical or laboratory evaluation for measles and mumps), three hepatitis $\mathrm{B}$ vaccine doses (HBV) and laboratory evidence of seroconversion (anti-HBs antibodies $\geq 10 \mathrm{mIU} / \mathrm{mL}$ ), two varicella vaccine doses or history of disease and influenza vaccine during the last season ${ }^{3}$. Those without immunization cards were considered not up-to-date.

The study was approved by the Ethics Committee of the Federal University of Sao Paulo. All participants signed the informed consent before enrolment.

From the Department of Pediatrics, Division of Pediatric Infectious Diseases, Universidade Federal de São Paulo, Brazil.

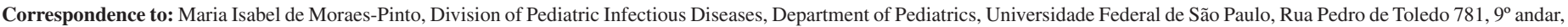
04039-032 São Paulo, SP, Brasil. Phone: 5511 5574.6471 Fax: 5511 5575.6928. E-mail: m.isabelmp@uol.com.br 


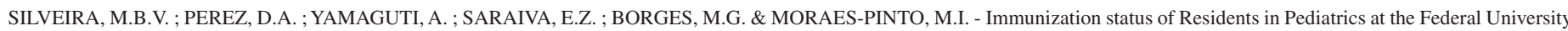
of São Paulo, Brazil. Rev. Inst. Med. Trop. Sao Paulo, 53(2): 73-6, 2011.

Statistical analysis was performed using Excel 97 (Microsoft, Redmond, USA).

\section{RESULTS}

All 64 Residents from the first to the third year were interviewed. Mean age was 27.5 years (range, 24.2 to 31.5 years) and $84 \%$ were female (54/64) (Table 1).

Table 1

Demographic characteristics of Residents in Pediatrics at the Federal University of Sao Paulo, in Sao Paulo, Brazil

\begin{tabular}{lc}
\hline Parameters & Data \\
\hline Mean age in years (range) & $27.5(24.2-31.5)$ \\
Number of female residents $(\%)$ & $54 / 64(84 \%)$ \\
Number of first year residents & 18 \\
Number of second year residents & 18 \\
Number of residents in pediatric specialities & 28 \\
\hline
\end{tabular}

Among the 64 residents, 17 (26.6\%) did not produce their cards. Only 2/64 (3.1\%) were up-to-date for influenza, 24/64 (37.5\%) for HBV, 35/64 $(54.6 \%)$ for $\mathrm{Td}, 40 / 64(62.5 \%)$ for measles, 33/64 (51.5\%) for mumps and $40 / 64(62.5 \%)$ for rubella. Varicella was the only disease from which all were considered immune (Table 2).

Table 2

Immunization status of Residents in Pediatrics for each disease/ vaccine according to the Brazilian Immunization Schedule for health care workers

\begin{tabular}{lcc}
\hline Health care worker schedule & $\begin{array}{c}\text { Number of immune } \\
\text { Residents }\end{array}$ & $\%$ \\
\hline $\begin{array}{l}\text { Three Hepatitis B vaccine doses } \\
+ \text { evidence of seroconvertion }\end{array}$ & $24 / 64$ & 37.5 \\
$\begin{array}{l}\text { Three Td vaccine doses and last } \\
\text { booster within 10 years }\end{array}$ & $35 / 64$ & 54.7 \\
$\begin{array}{l}\text { One measles vaccine dose or } \\
\text { history of disease }\end{array}$ & $40 / 64$ & 62.5 \\
$\begin{array}{l}\text { One mumps vaccine dose or } \\
\text { history of disease }\end{array}$ & $33 / 64$ & 51.6 \\
$\begin{array}{l}\text { One rubella vaccine dose or } \\
\text { history of disease }\end{array}$ & $40 / 64$ & 62.5 \\
$\begin{array}{l}\text { Two varicella doses or history } \\
\text { of disease }\end{array}$ & $64 / 64$ & 100.0 \\
$\begin{array}{l}\text { Influenza vaccine in the last } \\
\text { season }\end{array}$ & $2 / 64$ & 3.1 \\
\hline
\end{tabular}

Although not available free of charge in Brazil, two Residents had been immunized with meningococcal $\mathrm{C}$ conjugate vaccine. None had been immunized with tetanus-diphtheria-acellular pertussis (Tdap) vaccine.

Eighty-four percent (54/64) reported having received advice on immunization during medical school and 36\% (23/64), during the Residence course.

While $64 \%$ (41/64) considered themselves as being up-to-date with their vaccination, only $3.1 \%$ (2/64) met the Brazilian healthcare worker criteria for immunization.

\section{DISCUSSION}

While assessing the immunization status of the Residents in Pediatrics at a tertiary general hospital in São Paulo, Brazil, our study identified a worrying situation: the delayed vaccination of many professionals and their unawareness of the situation. Despite $84 \%$ having stated that they had received advice on immunization during medical school and $36 \%$, during the residence course, just $3.1 \%$ were up-to-date with their vaccinations.

In Brazil, the Ministry of Health provides vaccines free of charge with the goal of increasing vaccination uptake. Yet, the immunization of $\mathrm{HCW}$ is still a challenge to be overcome and different studies have dealt with this aspect of medical practice.

Hepatitis B is known to be one of the most frequent infections in the workplace 2 . While evaluating the risk perception of acquisition of vaccine preventable diseases among $\mathrm{HCW}$, our group recently found that hepatitis B was the most often mentioned among them ${ }^{11}$. Yet, we found $37 / 64(58 \%)$ Residents with records of three hepatitis B vaccine doses, but only $24(37.5 \%)$ of those were considered up-to-date because they had laboratory evidence of seroconversion.

In addition to three doses of $\mathrm{HBV}$ vaccine, laboratorial evidence of seroconvertion is necessary because knowledge of vaccine response will determine whether or not to repeat the vaccination schedule and the appropriate action in case of exposure to the virus ${ }^{1}$. In Spain, $7.8 \%$ of HCW evaluated showed non-responses after a three-dose series of HBV vaccine ${ }^{17}$.

Tetanus-diphtheria is another vaccine recommended for HCW. Only $54.7 \%$ residents were up-to-date for Td, but none had received Tdap. Of note, Td vaccine is offered free of charge in Brazil, but not the tetanusdiphtheria-acellular pertussis vaccine (Tdap). Different studies have shown an increase in cases of pertussis among adults and adolescents over the last 20 years ${ }^{7,18}$. This has been attributed to the waning immunity among adolescents and adults vaccinated during childhood. Today, this group is the major source of infection for unvaccinated children. HCW are especially at risk of acquiring pertussis and transmitting the infection to their susceptible patients and coworkers ${ }^{7,23}$.

The Brazilian Immunization Schedule recommends at least one dose of MMR vaccine for adults and HCW. In our study, $62.5 \%, 51.5 \%$ and $62.5 \%$ of HCW were immune against measles, mumps and rubella, respectively. It is important to note that those professionals were evaluated before a massive vaccination campaign for rubella that utilized the measles-rubella vaccine ${ }^{10}$. This campaign targeted adults between 20 and 39 years and it had a coverage rate of over $90 \%$ so that vaccination coverage for measles and rubella might have been higher if this study had been performed some months later ${ }^{5}$.

Control of varicella infection is important in health care facilities because varicella is a highly contagious infection and it frequently results 
in complications in adults, pregnant women and immunocompromised people. The $100 \%$ immunity for varicella noted in our study is mainly explained by the large number of Residents with a history of the disease (58/64). The high positive predictive value of history of varicella $-91.1 \%$ - and the high seroprevalence $-92.6 \%$ - found in our country among 21 to 30 year adults allow us to infer with a high degree of certainty as to an adequate immunity ${ }^{9}$. The only five Residents without history of varicella had been vaccinated.

The impact of influenza is well known to HCW and many countries have recommended influenza vaccine for HCW. Also, immunization programs have tried to encourage $\mathrm{HCW}$ to be vaccinated ${ }^{6,13,21}$. In 2005 the World Health Organization requested that influenza vaccination policies increased vaccination coverage of people at high risk, including $\mathrm{HCW}^{22}$.

However, HCW are known to resist being vaccinated against influenza. That was confirmed by our study, where just $3.1 \%$ of residents had received the influenza vaccine last season. HOFMAN et al. found that the most common reasons for refusal were: fear of adverse effects, misconception that vaccination can cause influenza and unsuitable time/ locations of vaccination - the third reason was the most common amongst medical house staff and students ${ }^{13}$.

Our data were collected before the influenza A H1N1 pandemic. Post pandemic, one would have expected a better understanding of the importance of influenza vaccines thus a change in attitude towards vaccination. However, recent data from the Northern Hemisphere showed a low uptake of vaccination against the 2009 influenza H1N1, similar to the seasonal vaccine uptake: in the USA, only $22 \%$ of HCW reported having received the vaccine by December $2009^{4}$. Some months before that, when the pandemic level was at phase 5, the intention of $\mathrm{HCW}$ to accept the vaccination was just $34.8 \%$ in Hong Kong. ${ }^{8}$ In another study conducted in Greece before the vaccination campaign, $83 \%$ of HCW indicated that they would not accept the pandemic influenza vaccine ${ }^{15}$.

Some have argued that compulsory vaccination on admission to medical school or Residence course could be a strategy to improve vaccination coverage among physicians ${ }^{19}$. Others propose that only some vaccines should be mandatory ${ }^{13,16}$. However, maybe facilitating access to vaccination could be a more democratic and important strategy as seen in a study in Korea, where a mobile cart system was used to provide on-site vaccination: an aggressive campaign with those and other measures, circulation of a newsletter that described the needs for and efficacy of influenza vaccine; color posters with key messages, times, dates and places of vaccination and a supply of vaccine at low cost - increased the vaccination rate from $23 \%$ to $78 \%$ in four years ${ }^{20}$. Information combined to vaccination in the workplace was also the strategy used in an institution in Boston ${ }^{18}$.

Another consideration is that the exposure of $\mathrm{HCW}$ and patients to vaccine preventable diseases can result in substantial medical and nonmedical costs (physician visits, diagnostic tests, treatment and time lost from work). Outbreaks in health care facilities can be even more costly.

Our study evaluated residents in Pediatrics who should, in principle, be the medical specialty most familiar with immunization and who most commonly prescribe vaccines for their patients. We found that the vast majority of them had delayed vaccination records and were unaware of this fact.

Both medical schools and pediatric residence courses should not only offer information but also check vaccination records in an effort to keep their healthcare workers' vaccinations up-to-date. Whatever the strategy chosen to increase vaccine uptake by $\mathrm{HCW}$, it should always include educational information on the risks and benefits associated with vaccinations in order to avoid unnecessary fears and disbeliefs.

\section{AUTHOR CONTRIBUTIONS}

Study conception and design: Mariana Bernardi Viviani Silveira, Deborah Ascar Perez, Alessandra Yamaguti, Eduardo Zegna Saraiva, Maria Gabriela Borges, Maria Isabel de Moraes-Pinto

Acquisition of data: Mariana Bernardi Viviani Silveira, Deborah Ascar Perez, Alessandra Yamaguti, Eduardo Zegna Saraiva, Maria Gabriela Borges

Analysis and interpretation of data: Mariana Bernardi Viviani Silveira, Maria Isabel de Moraes-Pinto

Manuscript writing: Mariana Bernardi Viviani Silveira, Maria Isabel de Moraes-Pinto

\section{RESUMO}

\section{Imunização de residentes em Pediatria da Universidade Federal de São Paulo, Brasil}

A vacinação de profissionais da saúde representa maneira eficiente de reduzir o risco ocupacional a infecções e de prevenir a transmissão nosocomial de doenças a pacientes vulneráveis. Apesar disso, atingir altas taxas de cobertura vacinal entre estes profissionais continua sendo um desafio. Avaliamos a situação vacinal dos residentes de Pediatria da Universidade Federal de São Paulo entre junho e dezembro de 2008. Suas carteiras de vacinação foram checadas e avaliadas de acordo com a orientação do calendário nacional para profissionais da saúde. Considerando as vacinas propostas, apenas 3,1\% dos 64 residentes estavam em dia com sua imunização. A vacina para Influenza foi a mais negligenciada $(3,1 \%)$ e sarampo e rubéola, as doenças com maior evidência de imunidade (62,5\%). Apenas 37,5\% dos residentes haviam recebido três doses da vacina para hepatite $\mathrm{B}$ e possuíam sorologia confirmando soroconversão. Além disso, a grande maioria dos residentes que estavam com atraso vacinal desconhecia este fato. Tanto as escolas médicas quanto os programas de residência em Pediatria deveriam não apenas orientar, como também checar os registros de vacinação num esforço para manter em dia a imunização dos profissionais de saúde.

\section{REFERENCES}

1. American Academy of Pediatrics. Hepatitis B. In: Pickering LK, Baker CJ, Kimberlin DW, Long SS, editors. Red Book: 2009. Report of the Committee on Infectious Diseases. 28 $8^{\text {th }}$ ed. Elk Grove Village: American Academy of Pediatrics; 2009. p 337-56.

2. Bonanni P, Bonaccorsi G. Vaccination against hepatitis B in health care workers. Vaccine. 2001;19:2389-94.

3. Brasil. Ministério da Saúde. Manual dos Centros de Referência para imunobiológicos especiais. Brasília: Coordenação de Comunicação, Educação e Documentação; 2006. 
SILVEIRA, M.B.V. ; PEREZ, D.A. ; YAMAGUTI, A. ; SARAIVA, E.Z. ; BORGES, M.G. \& MORAES-PINTO, M.I. - Immunization status of Residents in Pediatrics at the Federal University of São Paulo, Brazil. Rev. Inst. Med. Trop. Sao Paulo, 53(2): 73-6, 2011.

4. Centers for Disease Control and Prevention. Interim results: influenza A (H1N1) 2009 monovalent vaccination coverage - United States, October-December 2009. MMWR Morb Mortal Wkly Rep. 2010;59:44-8.

5. Centers for Disease Control and Prevention. Progress toward elimination of rubella and congenital rubella syndrome. The Americas, 2003-2008. MMWR Morb Mortal Wkly Rep. 2008;57:1176-9.

6. Centers for Disease Control and Prevention. Recommended adult immunization schedule. United States, 2009. MMWR Morb Mortal Wkly Rep. 2009;57:Q1-Q4.

7. Cherry JD. Epidemiology of pertussis. Pediatr Infect Dis J. 2006;25:361-2.

8. Chor JSY, Ngai KLK, Goggins WB, Wong MC, Wong SY, Lee N, et al. Willingness of Hong Kong health care workers to accept pre-pandemic influenza vaccination at different WHO alert levels: two questionnaire surveys. BMJ. 2009;339:b3391.

9. Clemens SAC, Azevedo T, Fonseca JC, Silva AC, Silveira TR, Clemens R. Soroepidemiologia da varicela no Brasil - resultados de um estudo prospectivo transversal. J Pediatr (Rio J), 1999;75:433-41.

10. Divisão de Imunização, Divisão de Doenças de Transmissão Respiratória. Centro de Vigilância Epidemiológica da Coordenadoria de Controle de Doenças. Secretaria de Estado da Saúde. National Vaccination Campaign against rubella in State of São Paulo. BEPA. 2008;5:16-19.

11. Dinelli MIS, Moreira TNF, Paulino ERC, da Rocha MC, Graciani FB, de MoraesPinto MI. Immune status and risk perception of acquisition of vaccine preventable diseases among health care workers. Am J Infect Control. 2009;37:858-60.

12. France. Institut de Veille Sanitaire. Calendrier vaccinal 2008. Avis du Haut conseil de la santé publique. Bull Épidémiol Hebdomadaire. 2008;16-17:129-48.

13. Hofmann F, Ferracin C, Marsh G, Dumas R. Influenza vaccination of health care workers: a literature review of attitudes and beliefs. Infection. 2006;34:142-7.

14 Loulergue P, Moulin F, Vidal-Trecan G, Absi Z, Demontpion C, Menager C, et al. Knowledge, attitudes and vaccination coverage of healthcare workers regarding occupational vaccinations. Vaccine. 2009;27:4240-3.
15. Rachiotis G, Mouchtouri VA, Kremastinou J, Gourgoulianis K, Hadjichristodoulou C. Low acceptance of vaccination against the 2009 pandemic influenza A (H1N1) among health care workers in Greece. Euro Surveill. 2010;15:pii:19486.

16. Ruef C. Immunization for hospital staff. Curr Opin Infect Dis. 2004;17:335-9.

17. Sabidó M, Gavaldà L, Olona N, Ramon JM. Timing of hepatitis B vaccination: its effect on vaccine response on health care workers. Vaccine. 2007;25:7568-72.

18. Sandora TJ, Gidengil CA, Lee GM. Pertussis vaccination for health care workers Clin Microbiol Rev. 2008;21:426-34.

19. Seale H, Leask J, MacIntyre CR. Do they accept compulsory vaccination? Awareness, attitudes and behavior of hospital health care workers following a new vaccination directive. Vaccine. 2009;27:3022-5.

20. Song JY, Park CW, Jeong HW, Cheong HJ, Kim WJ, Kim SR. Effect of a hospital campaign for influenza vaccination of healthcare workers. Infect Control Hosp Epidemiol. 2006;27:612-7.

21. Van Essen GA, Palache AM, Forleo E, Fedson DS. Influenza vaccination in 2000 recommendations and vaccine use in 50 developed and rapidly developing countries. Vaccine. 2003;21:1780-5.

22. World Health Organization. Influenza vaccines. WHO Position Paper. Wkly Epidemiol Rec. 2005;33:279-87.

23. Wright SWW, Edwards KM, Decker MD, Lamberth MM. Pertussis seroprevalence in emergency department staff. Ann Emerg Med. 1994;24:413-7.

Received: 17 August 2010

Accepted: 26 January 2011 